\title{
The opportunity space in the Lombok's art of Gendang Beleq and its relevance to the character education
}

\author{
Santriawan Azmi \\ Universitas Negeri Yogyakarta, Indonesia \\ Email: awansantriawan@gmail.com. \\ Hajar Pamadhi \\ Universitas Negeri Yogyakarta, Indonesia \\ Email: hpamadhi@yahoo.com
}

\begin{abstract}
The opportunity space in the Gendang Beleq art of Lombok provides thinking and interpretation for societies who watch the show. The value of opportunity space becomes essential because it influences the social environment and how people view the artwork. The art of Gendang Beleq contains cultural values, morals, and religious values. These three values lead to a domain of character education that sustains Lombok people's life guidelines.
\end{abstract}

Keywords: Opportunity Space, Gendang Beleq, Value, Character Education

\section{Introduction}

Lombok is an island with an area of 4,700 square kilometers located in east of Bali Island. Lombok Island is one of the two main islands, which makes up the province of West Nusa Tenggara. Lombok has a wide range of arts and cultures. The various cultures can be found in Lombok. One of the important 
elements in the cultural system is art, because through arts, human beings are able to obtain channels to express experiences of senses and ideas that educate their inner life. In other words, art is one type of human needs associated with the disclosure of a sense of beauty. Art is one element of a universal culture (Koentjaraningrat, 1990: 204). Sedyadi (1980: 24) states that art is the result of power, creativity, taste, and human initiative through an open attitude from any social class in the society. Meanwhile, Yoety (1990: 28) also states that art is a result of ideas and creativities of societies in terms of a very appropriate social process to produce creative ideas by displaying distinctive characteristics with their personalities.

Art is a human skill dealing with quality work, in terms of subtlety and beauty. Art that has long been known by the community is often called a tradition. Art has existed since the first time and been inherited to the young generation until now. Traditional art is the capital of the nation's cultural wealth that must be nurtured, grown and developed continuously. So, as one important part of culture, art is the expressions of creativities from the culture itself.

Traditional art was born out of a society's need that embraces various traditional arts (Kayam, 1981: 38). This interest is related to the needs of human beings in relation to the nature or the environment. Each tribe has art. Similarly, Indonesia is inhabited by hundreds of tribes, and every tribe has art that certainly epitomizes diversity. It can be seen from the many tribal works that still survive until now. One of them is the traditional art of Gendang beleq on Lombok island.

At the beginning of the seventeenth century; the Balinese, from Karangasem, came to Lombok and empowered in West Lombok. Original art and entrantscomplemented each other to create new genres. The most perceived influence acculturated with the local arts, the arts of the Hindu artistic culture, the nineteenth century of Balinese life and arts flourished in Lombok, along with the music, dance and theater that well-advanced in terms of the mask arts supported by the nobles, especially throughout West Lombok, and mostly Central Lombok and East Lombok. One of the arts that is influenced by the culture of immigrants is the art of gendang beleq which is an instrument of an elliptical percussion. Its material is made from a large log trunk and the center of the stem that is hollowed in the middle of both sides with cow leather, goat or buffalo. The hit will sound "Dang" or "Dung". The "Dang" sound seems to be the beginning of naming of the arts, while the prefix "Gen" is just a 
complement to facilitate the mentioned name. The word beleq in Sasak means 'great', thus, the gendang beleq means the Great Drum.

Initially, the art of gendang beleq was just a Jidur of a large drum shaped like a Bedug, a flute and a gong. However, after the influence of Bali, there is a change of form and some other additional instruments such as small flute, Gong Genjeq or Kemong Gantung, Kempul, Cenceng Perembaq or Pengecek, Reong, and Rincik.

Gendag beleq is said to have been used in the ancient time as a drum war, which accompanied and encouraged the warriors and warriors of the kingdom of Lombok who went to or returned from the battlefield. As time went by, gendang beleq also functioned as an accompaniment of traditional ceremonies such as Merariq (wedding), Ngurisang (baby haircut), Nghitanang or Cut Loloq (circumcision), and Begawe beleq (big ceremony).

Kendhang is one of the Javanese musical instruments in gamelan that serves to organize the rhythm and belongs to a group of "membranophones" musical instruments whose source of sound comes from the skin membrane or other materials played by the way at using a drum or hand. According to a book entitled "Know Easy and Complete Javanese Gamelan Karawitan Art" by Ferdiansyah (2010: 23), the gamelan derives from the action word nggamel (in Javanese), or gamel which means to hit or beat, followed by the suffix "-an" which changes it into a noun. The term gamelan means a unity of musical instruments that can be played together. The materials used for making drums are made of wood which perforated the middle part, while each side of the drum hole is covered by the leather made of goat skin, cow skin, or buffalo skin. The previously mentioned drum shows the existence of various shapes, sizes and materials used, such as small, medium-sized, large-sized drums.

The drum in Sasak means gendang, while beleq in Sasak means big. So this gendang beleq is a very large musical instrument (up to one meter in length). This instrument is played by standing, and strapping the gendang attached on the shoulders of Sekahe. The beleq drum has a pair, in which each pair has a different name and a sizing name. The larger size is called gendang beleq mame, while the smaller drum is called the gendang beleq nine. According to Sudarsono (in Depdikbud NTB province, 1991: 25), this gendang beleq is also used to accompany a prayer to ask for the rain fall to the creator, and then the Beleq Gender is still sacred. In gendang beleq elements of decorative motifs are basically geometric motifs, motifs of plants and animal motifs. The three decorative motifs can appear alone, but there are also combinations so that new motifs appear, and 
the name of decorative special motifs in gendang beleq is not specifically found.

Gendang beleq art is one of a series of events presented at the wedding ceremony, ngurisan (baby haircut), circumcision, and big events in the community of Sasak tribe. This art is one art that is often used by the people of Lombok, especially Sasak community in general.

Gendang beleq is a traditional musical art instrument whose size is more than one meter made of large logs perforated in the middle and on each side of the drum covered with cow leather, buffalo, goat in order to produce good and high sounds (Depdikbud NTB province, 1991: 23).

The events occurring in the history of Lombok have formed certain conditions for the art tradition of Sasak people. Almost throughout the nineteenth century Balinese life and arts flourished in Lombok, and in reference to the surroundings. The Balinese had consolidated their power with highly developed music, dance and theater supported by nobles, especially throughout West Lombok and mostly Central Lombok and East Lombok.

This power makes Lombok an archipelago that has a culture similar to Balinese culture. It can be seen from the traditions in Lombok that are not much different from the Balinese traditions. Davit Harnish, Ibid, 21 (in Depdikbud NTB province, 1991: 12) states that in every "colonial" situation, in the field of culture or arts there is a crossroad that must be passed. (1) If the colonial culture or art is better, stronger and more beautiful, then the colonized people will imitate the culture or art of immigrants. (2) Conversely, the occupiers will imitate the property of the colonized people.

\section{Results and Discussion}

\section{History of Gendang beleq}

The art history of gendang beleq and its development has survived until now and it cannot be separated from the history of the tradition and the population in which arts are developed. The art has passed many decades of changes, but its existence can be brought to a hereditary tradition that will continue to be preserved by the Lombok community. It is, therefore, important to know the history and development of gendang beleq art through various methods in order to get closer to this art. To know the history of art gendang beleq, it is necessary to know the beginning of existence and development of gendang beleq.

Gendang beleq was born in the heyday of Islam and Hindu in Lombok. 
The appearance of gendang beleq at that time occurred around the time of colonialism, gendang beleq is the inheritance of the Sasak ancestors and it has survived until now as an art that has a strong sanctity. In this gendang beleq art, there is an element of animism in the process of making up its implementation. If viewed from the literature review, both from Lontar Babad Lombok and Babad Selaparang no one wrote the celebration event using the gendang beleq art. However, Kamarudin in his research by Depdikbud NTB province emphasizes that gendang beleq emerged in the days of colonialism. The existence of gendang beleq certainly plays a very important role for the indigenous Sasak people, because in every big event people consider that it will not be complete as an event unless the gendang beleq is presented.

Gendang beleq is created in pairs, because the Sasak people believe that every living creature has its different type of pair, that is, gendang beleq mame and gendang beleq nine. Then in creating two types of different drums, we can distinguish gendang beleq mame from beleq nine in size. The difference in the size of the gendang mame and nine is approximately three centimeters, and if we hit them, the beleq mame has a sound louder than beleq nine. The making of a paired gendang beleq is also associated with the word of God that creates everything in pairs.

When the kingdom of Karangasem Bali came to the island of Lombok for building their power in West Lombok, a lot of Balinese arts were introduced to Lombok and were enriching the cultural treasures of Sasak, as the result of the meeting of some cultures. The original art and entrants complement each other to create a new art. The traditional art form of gendang beleq that we find today is a transition of a drum form. When Anak Agung Gede Ngurang Karang Asem was ruling on Sasak earth at that time, a lot of development occurred especially in arts on the land of Sasak, for example, gendang beleq. Basically, this gendang beleq has undergone a change from a drum that can merely be played in one place. Then the culture of Bali was able to influence the birth of a new art at that time.

Balinese culture has greatly influenced Sasak culture since circa 1800 AD. This art of gendang beleq only consisted of a large drum or jidur that was only played in one place. Then a change began to occur, such as the drum can be played by way of carrying it on the back, and additions to the instrument increased in that it was previously accompanied only by a gong and a flute. This art equipment is growing and growing in accordance with the tools used in today's tawaq-tawaq art event. 
Journal of Social Studies (JSS), Volume 15, Number 1, 2019: 35-46

\section{Gendang beleq Function in the Past and Present}

The difference in Beleq's Gender function in the past and present is very much different, the function in the future is only used when the king of Lombok is at war and the welcome of certain big guests, but the comeback of the gendang beleq era is changed to complement the cultural ceremony of the Sasak tribe. The information about the past and present drums is elaborated as follows:

\section{a. Gendang Beleq the Past}

The function of gendang beleq in the past was as a gamelan of the army that was owned by every king in Lombok. When the warrior set out for a battle of war, every sound which was produced had its own meaning. Besides, gendang beleq served as a tool of giving cues while in combat.

The followings are the meanings of gendang beleq sounds when produced in the battle:

1) If the gendang beleq sounds rather loud and fast with a steady rhythm, it indicates that the troops are fighting fiercely.

2) When the gendang beleq sounds dashed and rhythmic, it signifies the troops in a state of chaos, or running for cover and asking for help.

3) If the sound of the gendang beleq sounds the same as the first, it denotes the victory.

4) If the gendang beleq sounds slow and rhythmic, it indicates that the battle is over.

b. Current Functions of Gendang Beleq

1) Ceremony Function: gendang beleq in this ceremony is a medium of bridal to the bride's house after the legitimate wedding ceremony called kobul in a wedding ritual.

2) Entertainment function: gendang beleq is often staged along the road while accompanying a pair of bride. Sometimes in this art performance, there is also additional entertainment from the family and spectators who come to dance.

\section{The Opportunity Space in the Art of Gendang Beleq}

This art form is a result of collaboration of gendang beleq musical 
instrument rhythmically and melodic instruments made of brass presented with traditional gending. Gending which is often presented in the art of gendang beleq is gending oncer (for circumcision) and gending cilimanye (for the wedding).

Gending oncer is presented with a tap or a $4 / 4$ tempo and tends to be monotonous, while gending cilimanye is presented with the tempo of Allegro (fast tempo) at the speeds between 126-138 steps per minute so as to bring the opportunity space to the audience and to provide a wide range of thinking and interpretation (Langer : 69). Then the value of opportunity space becomes important when a work of art influences the environment of society and how citizens view the work of art.

In another dimension, a work of art can be a meeting ground or gathering place for a (group) of communities. Performing arts such as gendang beleq (beleq drums) can be highlighted in community tradition events, and they can also be the subject of conversations in an important social gathering for the community. It is not excessive that the artwork potentially becomes the identity and sign of the maturity of a society.
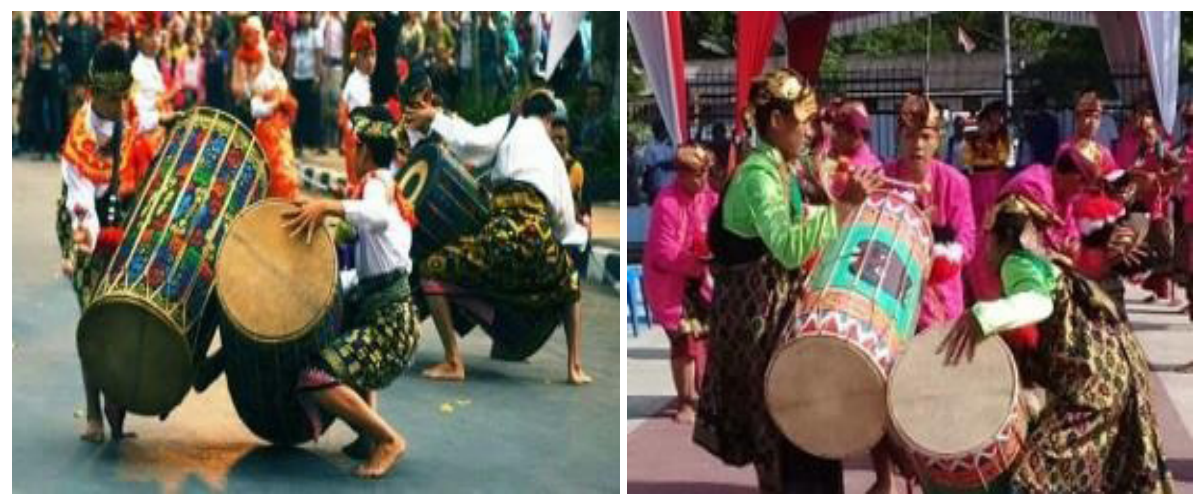

Figure 1. The art drum of beleq

\section{The Meaning of Gendang beleq Philosophy and its relevance to the character education}

Gendang beleq has a philosophical value and is also sacred for the Sasak people. The tribe of Sasak people think that gendang beleq has a beauty value, perseverance, patience, policy, thoroughness, and heroism. These values are always expected to blend with the hearts of the Sasak people.

At the times of the first kingdoms, gendang beleq were often used in every royal activity and as accompaniment when the soldiers set out for war. It aims 
to thrill the heart and give the spirit to soldiers when facing the enemy, so the influence of gendang beleq at that time leads to courage possessed by the society of Sasak tribe inseparable from the values in the gendang beleq.

As a traditional art of Sasak, the gendang beleq contains noble values that serve as the purpose of implementation. The values in such arts include cultural values, moral, and religion.

(1) Cultural Values

Gendang beleq used in ceremonies is a form of appreciation to the relics of ancestors of society in Lombok, whereas the relics are a form of traditional art emerged and developed in the soil of Sasak, and then this art should be preserved as local culture and cultural identity of Sasak tribe.

(2) Moral Values

As an art, gendang beleq has a value for a wedding procession, and ngurisan (first baby haircut) and circumcision. It is also used in other major events that preserve moral values referred to as a form of witness ceremony in which the community celebrate a wedding ceremony and it should not trigger a slander in the next life. In the event or wedding ceremony, this gendang beleq is used as a form of moral support from both sides of the bride's family.

(3) Religion Values

Traditional art is created as a form of support in the event when someone circumcises and gets married, and it is a command or a necessity for Moslems to get married legitimately and build a legal marriage relationship between a pair of humans. Apart from the meaning of this execution, the intention is that the word of God has been addressed for every creature who is always created in pairs. Similarly, gendang beleq is created in pairs just like the creation of God.

\section{Contexts of Identity and Representation of Lombok People's Life in the Art of Gendang Beleq}

Around the 1980s gendang beleq declined in popularity due to the religious and tradition conflicts, in which the Islamic group said that gendang beleq opposed to the syariah because it was made of metal. Nonetheless, there are still many people who use it, and 1995 was the culmination year of gendang 
beleq, which was replaced by kecimol as a popular art in Lombok. The naughty ceremony no longer used the Gendang Beleq, but it used kecimol. kecimol was very popular because this art used dangdut songs in its show. In 2000, kecimol became unpopular again due to various negative facts that led to the show of kecimol, and one of them was kecimol which was identical to the riot caused by the participants who drank the liquor.

The identity representing the entity arises from the relationship between marks and markers. According to Friedman (1994), representation is a place of meaning interpretation. This means that there are many differences in interpreting the meaning of a sign/art. The real representation is merely the reappearance of the established identity. The discussion focusing on the art of gendang beleq found in the Lombok island shows various ethnics. This paper discusses how the tagging process can show the representation in which the meaning differences emerge. Thus, it can be assumed that the emergence of identity in an ethnic group is worth considering.

In early 2001, gendang beleq had not been popular yet but during the implementation of regional autonomy, gendang beleq became popular again. This is because there is a desire from the local government to revitalize the sign of culture as a representation of its identity. This is supported by the Sasak community that make gendang beleq a representation of Sasak identity. The religious group has no more problems, so that the goal can be achieved. The government's efforts in assisting the discourse were realized through the Cultural Appreciation Week held in September 2001. Currently, gendang beleq is even delivered in West Nusa Tenggara cultural event at Taman Mini Indonesia Indah.

\section{Conclusion}

\section{Gendang beleq History}

Gendang beleq was born in the heyday of Islam and Hindu in Lombok. The appearance of gendang beleq at that time occurred around the time of colonialism. gendang beleq is the inheritance of the Sasak ancestors that has survives until now, and as an art, it has a strong sanctity. In this gendang beleq art, there is an element of animism in the process of making up its implementation.

This is because there is no historical data about the art of gendang beleq in the form of writing; there is no awareness of local government to document the arts that exist in Lombok. 
From the literature review of both Lontar Babad Lombok and Babad Selaparang, it indicates that no one wrote in what celebration events the gendang beleq art was used. However, based on Kamarudin's research by Depdikbud NTB province, gendang beleq emerged in the days of colonialism.

\section{Gendang beleq Function in the Past and Present.}

The function of gendang beleq in the past and the present is very different. Meanwhile, its future function only symbolizes the Lombok king of war and the welcoming of certain great guests, but the succession of the gendang beleq era is in priority as a complement to the Sasak privacy ceremony.

\section{The Opportunity Space in the Art of Gendang beleq}

The opportunity space in a work of art can provide a wide range of thinking and interpretation when viewing artwork. The value of opportunity space becomes important when a work of art influences the environment of society and how citizens view the work of art.

\section{The Meaning of Gendang beleq Philosophy Relevance to the Character Education}

Gendang beleq has a philosophical value and is also sacred by the Sasak people. The tribe of Sasak people think that gendang beleq has a beauty value, perseverance, patience, policy, thoroughness, and heroism.

These values are always expected to blend with the hearts of the Sasak people.

As a traditional art of Sasak, gendang beleq contains noble values that serve as the purpose of implementation. The values in question includes arts and cultural values, moral and religion values.

(1) Cultural Values

Gendang beleq is used in ceremonies and it is a form of appreciation to the relics of ancestors of society in Lombok, whereas the relics are the forms of traditional arts emerged and developed further. This art then should be preserved as a local cultural identity of the Sasak tribe.

(2) Moral Values

The art of gendang beleq, in addition to having value for a wedding procession, is used in the ngurisan (first baby haircut) ceremony, the mayor's event, and circumcision. It has the moral value referred to as a form of witness ceremony in the community, for example, a marriage 
The opportunity space in the Lombok's art of Gendang Beleq and its ... (Santriawan Azmi, Hajar Pamadhi)

tradition that really happens and it is not planned to trigger a slander in the next life.

\section{Representation of Lombok People's Life in the Art of Gendang Beleq.}

The discussion in this paper focuses on the art of gendang beleq found on the island of Lombok in various ethnics. This paper examines how the tagging process can show the representation in which a meaning may be different, but it can be assumed that the emergence of identity in an ethnic group produces contextual art meanings.

\section{References}

Tsuchiya, K., \& Yassin, H. B. (1992). Demokrasi dan kepemimpinan: kebangkitan gerakan Taman Siswa. Jakarta: Balai Pustaka.

Ferdiansyah, F. (2010). Kesenian karawitan- gamelan Jawa. Yogyakarta: Garailmu.

Langer, S. K. (1953). Feeling and form (p. 318). London: Routledge and Kegan Paul.

Koentjaraningrat. (1990). Pengantar ilmu antropologi. Jakarta: Rineka Cipta.

Scheler, M. (2012). Der Formalismus in der Ethik und die materiale Wertethik. BoDBooks on Demand.

Sedyadi, E. (1980). Tari: Tinjauan dari berbagai segi. Jakarta: Pustaka Jaya.

Yoety, O. (1990). Komersialisasi seni budaya dalam pariwisata. Jakarta: Rineka Cipta.

Team Depdikbud. (1991). Deskripsi Tari Gendang Beleq Nusa Tenggara Barat. NTB: Depdikbud.

https://kontikicottage.files.wordpress.com/2011/11/gendang_balek.jpg 
Journal of Social Studies (JSS), Volume 15, Number 1, 2019: 35-46 